\title{
Linkage of aerosol optical depth with rainfall and circulation parameters over the Eastern Gangetic Plains of India
}

\author{
P Parth Sarthi* $『$, Sunny Kumar, Archisman Barat, Praveen Kumarø, \\ Ashutosh K Sinha and Varsha Goswami \\ Department of Environmental Science, Central University of South Bihar, Gaya, Bihar, India. \\ *Corresponding author.e-mail: drpps@hotmail.com
}

MS received 20 September 2018; revised 24 January 2019; accepted 19 April 2019; published online 19 June 2019

The aerosol optical depth (AOD) is an important physical parameter and dimensionless number. The possible link between AOD and variability of summer monsoon rainfall and surface temperature over the densely populated Gangetic Plain may be used to assess change in weather and climate over the Plain. For examining the impact of AOD on summer monsoon rainfall and surface temperature, monthly data of AOD for the period of 2000-2015 are obtained from a remotely sensed moderate resolution imaging spectro-radiometer sensor at $550 \mathrm{~nm}$ and at a surface resolution of $1^{\circ} \times 1^{\circ}$. For the period of 2000-2015, rainfall and surface temperature data at a resolution of $1^{\circ} \times 1^{\circ}$ are obtained from Indian Meteorological Department (IMD) and surface wind data are obtained from National Centers for Environmental Prediction (NCEP). Summer monsoon rainfall and AOD are inversely related during 2000-2015. On an average, a difference in the mean monthly surface maximum and minimum temperatures increases (decreases) with a decrease (increase) of AOD. The high degree of correlation exists between AOD and a difference in $T_{\max }$ and $T_{\min }$ during January to June-July. In winter months, relative strength of negative vorticity over the Gangetic Plain and positive vorticity in the adjacent area may be cause of more dispersion of AOD in February in comparison with that in December and January and therefore more AOD is noticed in January and December.

Keywords. Aerosol optical depth (AOD); Indian Gangetic Plain; temperature; vorticity; MODIS.

\section{Introduction}

Aerosols originating from natural and anthropogenic sources have been influencing air quality, Earth's radiation budget (through scattering and absorbing the incoming solar and outgoing terrestrial radiation) and consequently changing regional and global climate. The variability in aerosol concentration has been significantly impacting the regional scale. The anthropogenic aerosols (sulphate and carbonaceous aerosols) have increased substantially in recent decades, especially over urban's industrial regions and have direct impact on cloud formation and the rainfall distribution because aerosols act as cloud condensation nuclei $(\mathrm{CCN})$ and influences cloud formation, rainfall and climate through radiative forcing and microphysical effects (Rosenfeld 2000; Li 2004; Li et al. 2007, 2011a, b; Nakajima et al. 2007; Huang et al. 2014; Guo et al. 2016). For assessing changes in weather and climate due to aerosol concentration, aerosol optical depth (AOD) is an important physical 
parameter and denotes aerosol distribution within a column of air from Earth's surface to the top of the atmosphere and is used to measure urban haze, smoke particles, desert dust, sea salt and others (Massie et al. 2004).

In order to understand the variation of aerosols and their impact on regional climate and monsoon rainfall, several field experiments such as INDian Ocean EXperiment (INDOEX), Aerosol Characterization Experiment (ACE) Asia and East Asian Studies of Tropospheric Aerosols: An International Regional Experiment (EAST-AIRE) have been carried out (Ramanathan et al. 2001; Li et al. 2007). The observational study on the relationship between aerosols and monsoon rainfall, and associated change in wind circulation over Indian subcontinents and other places of the world has been carried out by various researchers (Hansen et al. 1997; Ackerman et al. 2000; Satheesh and Ramanathan 2000; Ramanathan et al. 2001, 2005; Kaufman et al. 2002; Meehl and Arblaster 2002; Jin et al. 2005; Chung and Ramanathan 2006; Goswami et al. 2006; Kaufman and Koren 2006; Lau and Kim 2006; Lau et al. 2006; Wang et al. 2009a, b; Bell et al. 2008; Lau et al. 2008; Meehl et al. 2008; Ramachandran and Kedia 2010; Cowan and Cai 2011; Prabha et al. 2011; Freud and Rosenfeld 2012; Konwar et al. 2012; Manoj et al. 2012; Nair et al. 2013; Solmon et al. 2015). The modelling study on aerosol, monsoon rainfall (Parth Sarthi et al. 2015, 2016) and associated changes in circulation over Asian regions has also been examined by previous researchers (Ramanathan et al. 2005; Li et al. 2009; Zhang et al. 2009, 2010a, b, 2012; Guo et al. 2013; Jiang et al. 2013; Song et al. 2014). They suggested the reduction in surface solar radiation due to absorption and scattering by aerosols cools the northern Indian Ocean, reduces evaporation, causes a spin down of the local Hadley cell circulation and weakens the Indian summer monsoon precipitation (Menon et al. 2002; Ramanathan and Crutzen 2003; Bollasina et al. 2011; Ganguly et al. 2012a, b). The spatial and temporal variation in AOD is important due to a fast increase in aerosol emissions over India in the last two decades (Ramachandran and Jayaraman 2003; Streets et al. 2009) and therefore seasonal and annual trends in AOD over different regions in India may be helpful in understanding the effect of aerosols on summer monsoonal rainfall variability. Gautam et al. (2009a) found that the remotely sensed total ozone mapping spectrometer (TOMS) aerosol index over northern India $\left(25-35^{\circ} \mathrm{N} ; 69-82^{\circ} \mathrm{E}\right)$ during the premonsoon (March-April-May) shows an increasing trend since 1979. The trends in AOD over the different regions, seasons (winter and summer) and annual mean scales are studied.

Another impact of AOD is changes in surface temperature. Over industrialised parts of China, Zhou et al. (2004) found a larger decrease in the diurnal temperature range at 194 meteorological stations during 1979-1998. Roy (2008) found higher concentrations of AOD over the densely populated Gangetic basin for summer and winter seasons for the period of 2000-2005 and showed contrary relationship during the winter season. In recent years, aerosols have been substantially increased over the Indo-Gangetic Plain (IGP); dust particulates accumulated and significantly influenced AOD properties (Dey et al. 2004; Singh et al. 2004; El-Askary et al. 2006; Prasad and Singh 2007a,b; Gautam et al. 2009b) as well as the regional radiation budget (Singh et al. 2005; Pandithurai et al. 2008). Prasad et al. (2006) show very high AOD $(>0.6)$ over the Gangetic Plain during the summer season. During 2002, a high concentration of AOD $(>0.6)$ is observed in the western part of the Ganga basin and AOD of greater than $0.5-0.6$ in the central region which may be due to the failure of summer monsoon rainfall in 2002. The lowering of AOD in 2003 may be correlated with good summer monsoon in 2003. They found that very high AOD is present over the Ganga basin throughout the year.

An earlier study is mostly focused on the spatial and temporal variability of AOD over all India and but not much confined to the states of Bihar and Uttar Pradesh over the Eastern Gangetic Plain of India. These states are entirely land locked and adjacent to West Bengal (a deep humid state). The current study is focused on the temporal and spatial variability of remotely sensed AOD over the Eastern Gangetic Plain (includes the states of Uttar Pradesh and Bihar) of India where AOD dominates and related erratic behaviour of summer monsoon largely affecting agriculture as well as night-time temperature during the winter season. Further, increasing pollution load over the study area is very much concerned to human health (Pisudde et al. 2017) during the winter season (December-January-February). Therefore, in the current paper, the following objectives are aimed for the study period of 20002015: 


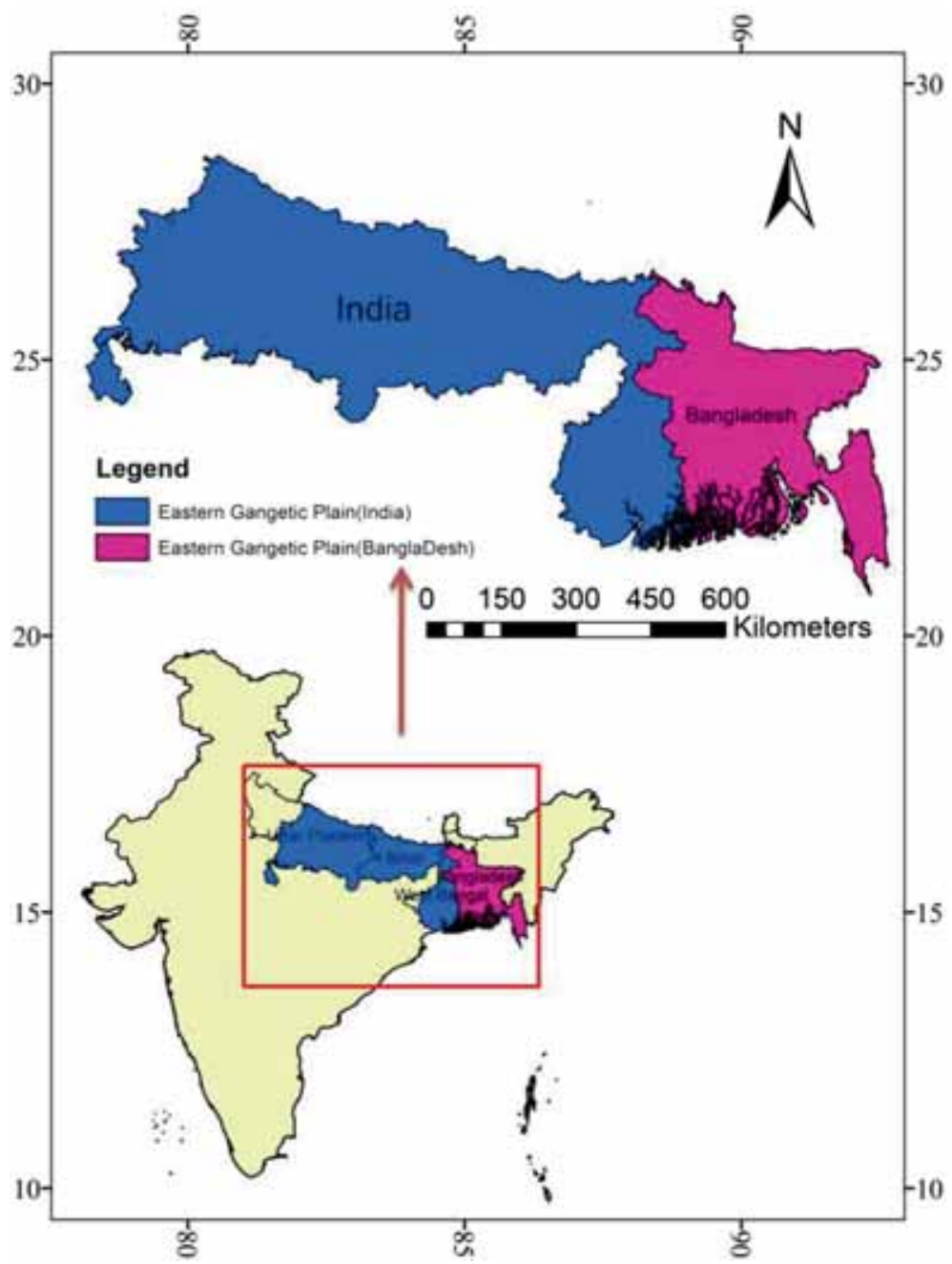

Figure 1. Study area showing the state of IGP, Uttar Pradesh, Bihar, West Bengal and Bangladesh.

(1) The spatial and temporal variability of AOD over the Gangetic Plain of India.

(2) The linkage of AOD with rainfall and circulation parameters (i.e., temperature and vorticity).

The importance of this research work is focused on the probable cause of occurrence of AOD in terms of surface temperature and vorticity and how it is influencing the summer monsoon rainfall pattern. The study area and data are discussed in section 2 . Results and discussion are given in section 3 and conclusion is provided in section 4 .

\section{Study area and data}

In the current study, the states of Uttar Pradesh and Bihar over the Eastern Gangetic Plain of India are considered for the analysis purpose (as shown in figure 1); however, the discussions are conceded over adjacent areas like foothills of the Himalayas, West Bengal and Bangladesh. The plain of the river Ganga is a densely populated area and agriculture is dominant profession for their economy. Therefore, any change in the rainfall pattern would affect agriculture production. Also, the change in surface temperature during the winter is important for crops. To fulfil aimed objectives, the remotely sensed moderate resolution imaging spectro-radiometer (MODIS) derived AOD data are considered. These remotely sensed data are collected twice daily by NASA's Terra and Aqua satellites and is available at medium to high resolution across the globe at different spatial and temporal scales. In current analysis the MODIS (at $550 \mathrm{~nm}$ ) at a resolution of $1^{\circ} \times 1^{\circ}$ is considered for the period of 2000-2015.

The rainfall and surface temperature data at a resolution of $1^{\circ} \times 1^{\circ}$ during $2000-2015$ are obtained from the Indian Meteorological Department (IMD) 
Table 1. Details of data type, source, resolution and period.

\begin{tabular}{|c|c|c|c|}
\hline Data type & Data source & $\begin{array}{l}\text { Surface } \\
\text { resolution }\end{array}$ & Period \\
\hline Rainfall & IMD & $1^{\circ} \times 1^{\circ}$ & $2000-2015$ \\
\hline $\begin{array}{l}\text { Surface temperature } \\
\qquad\left(T_{\max } \text { and } T_{\min }\right)\end{array}$ & IMD & $1^{\circ} \times 1^{\circ}$ & $2000-2015$ \\
\hline Surface wind & NCEP & $2.5^{\circ} \times 2.5^{\circ}$ & 2000-2015 \\
\hline $\mathrm{AOD}$ & $\begin{array}{l}\text { giovanni.gsfc.nasa.gov/ } \\
\text { giovanni }\end{array}$ & $1^{\circ} \times 1^{\circ}$ & 2000-2015 \\
\hline
\end{tabular}

while the surface wind data are obtained from the National Centers for Environmental Prediction (NCEP) for the period of 2000-2015. Details of the data are given in table 1.

\section{Results and discussion}

\subsection{AOD, rainfall and surface temperature}

In this section, the relationship among the remotely sensed AOD, observed rainfall and surface temperature of IMD over India is examined during different time periods. Figure 2 shows the variation of AOD during the pre-monsoon (March-AprilMay), monsoon (June-July-August-September), post-monsoon (October-November) and winter (December-January-February) seasons during 2000-2015. It reveals that AOD is remarkably increased during the winter season followed by the monsoon, post-monsoon and pre-monsoon. Probably, the high AOD during the monsoon may be arised by advection of dust from the Arabian Desert and transported by surface westerly winds. The aerosol during the pre-monsoon months (March, April and May) (Dey et al. 2004), postmonsoon (October, November) and winter (December, January and February) may be due to the dust and biomass burning, over the study area. During the winter season (December-February), the aerosol loading is dominated by the anthropogenic contribution (Tripathi et al. 2006; Jimenez et al. 2009) especially by agricultural waste burning and the urban/industrial aerosols (Guttikunda et al. 2003; Sharma et al. 2003) over the Gangetic Plain.

To examine the relationship between AOD and summer monsoon rainfall, the time series of average AOD and JJAS (June-July-August-September) rainfall during 2000-2015 is considered (figure 3). Both are varying in almost opposite directions (Ramachandran and Cherian 2008; Ganguly et al. 2012a,b) i.e., during high (low) AOD, rainfall is

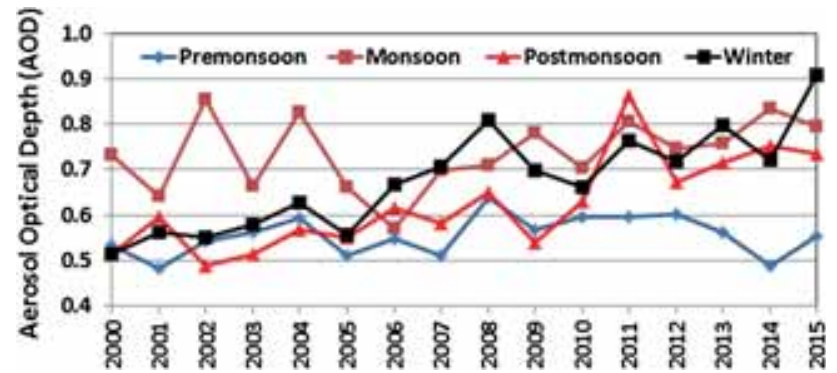

Figure 2. Variation of AOD in pre-monsoon (MAM), monsoon (JJAS), post-monsoon (ON) and winter (DJF) seasons during 2000-2015.

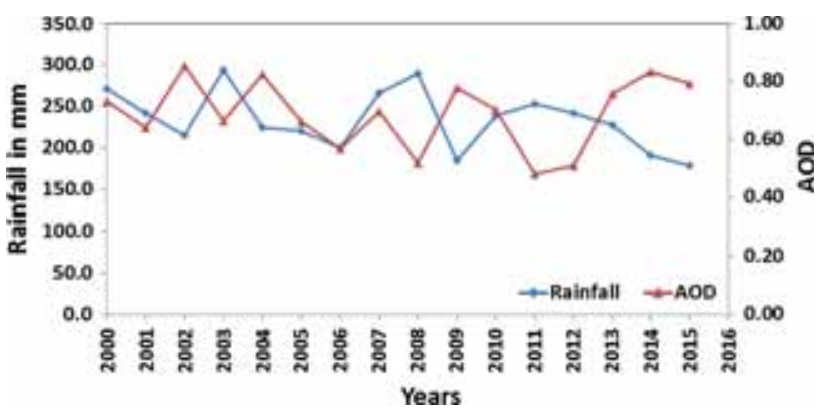

Figure 3. Variation of rainfall (in $\mathrm{mm}$ ) and AOD in JJAS during 2000-2015.

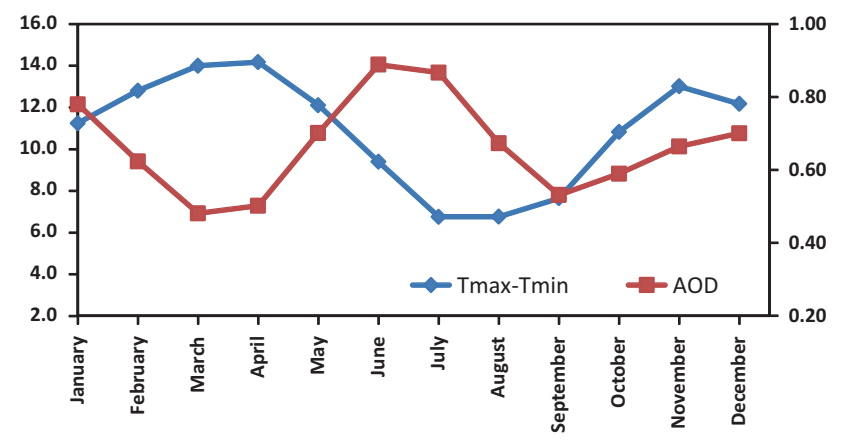

Figure 4. Monthly variation of $T_{\max }-T_{\min }$ and AOD during 2000-2015.

low (high). During 2002-2004 and 2008-2015, the inverse relationship exists between AOD and JJAS rainfall. It seems that aerosol particles are being 
(a)

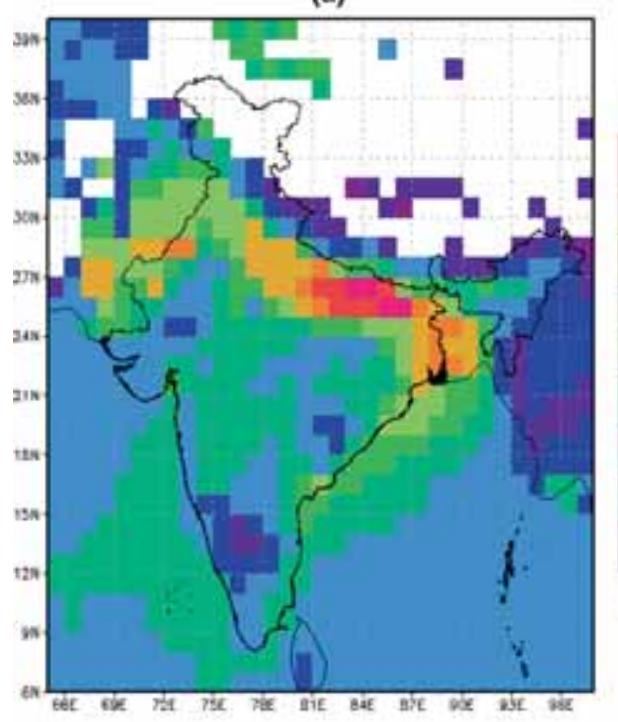

(b)

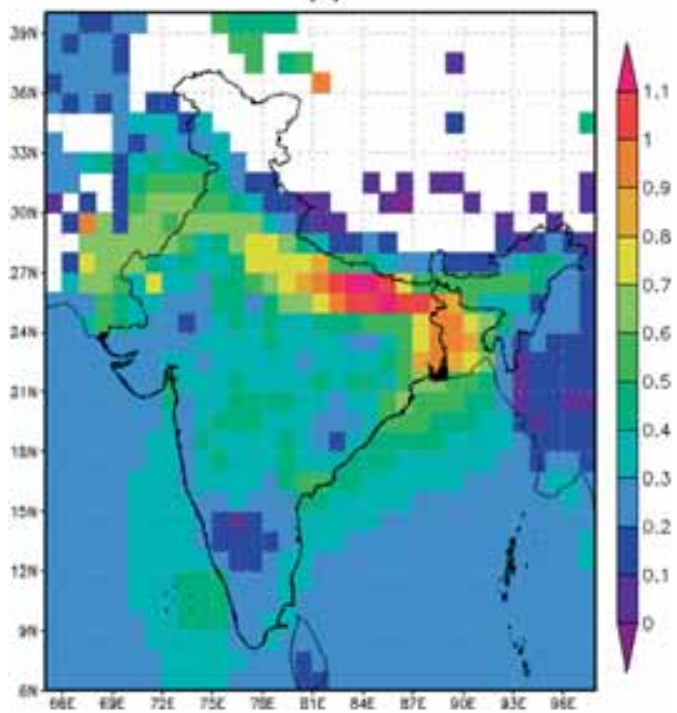

(c)

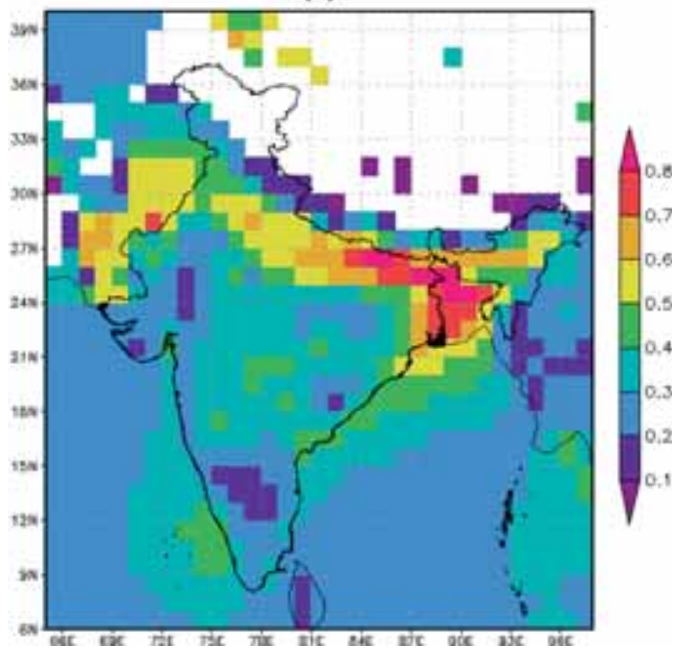

Figure 5. Spatial distribution of AOD in (a) December, (b) January and (c) February during 2000-2015. (a)

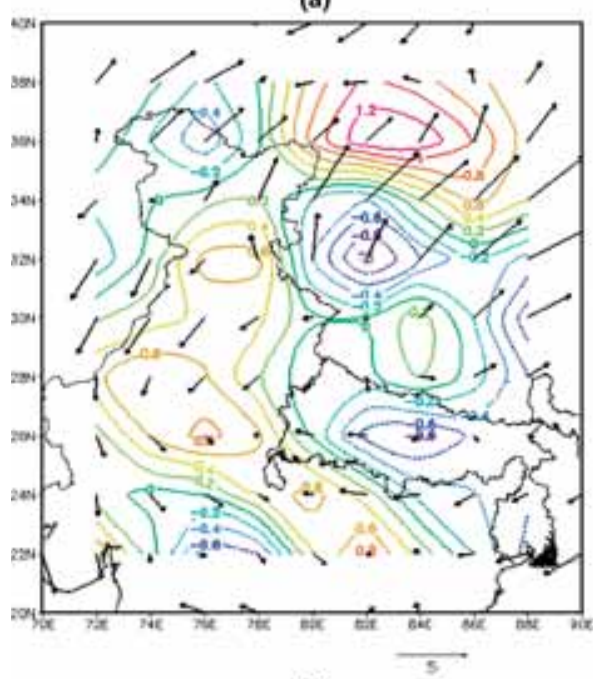

(b)

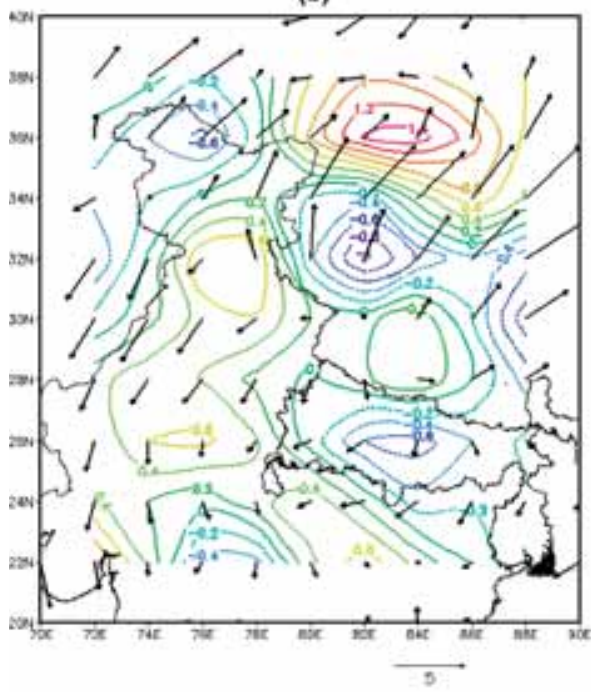

(c)

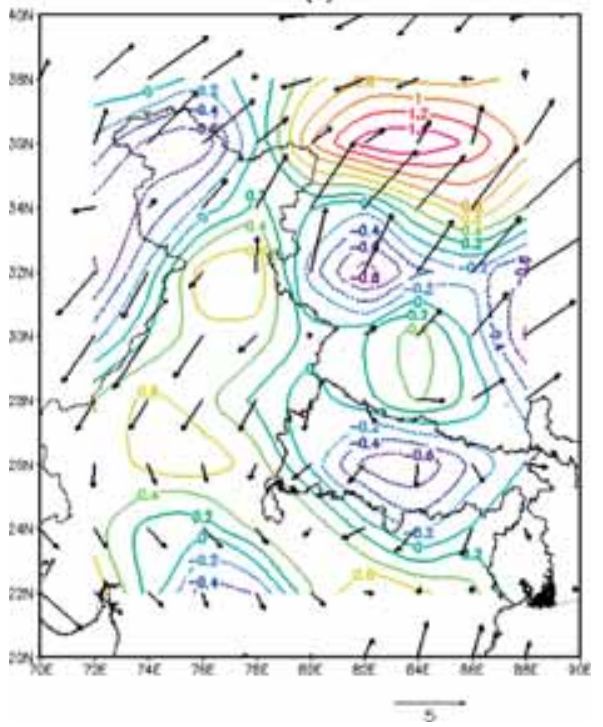

Figure 6. Spatial distribution of vorticity at $1000 \mathrm{hPa}$ in (a) December, (b) January and (c) February during 2001-2015. 
washed during that period. This inverse relationship does not exist for the individual years of 2001, 2005, 2006 and 2007; the inverse relationship is dominating during 2002-2004 and 2008-2015. The increasing level of AOD affects the Earthatmosphere radiation budget by scattering and absorbing the incoming solar radiation. Such a process influences the formation of cloud through cloud CCN and consequently the rainfall. Aerosol may increase the reflectivity of the cloud and causes cooling effect on land surface that may further decrease the rainfall. AOD may also absorb, reemit as thermal radiation, heat the air mass and may cause evaporation of cloud droplets and finally decreases the rainfall. In other words, it may be possible that AOD increases the temperature of the lower atmosphere by heat and evaporates cloud droplets and therefore rainfall seizes.

Figure 4 shows the monthly mean distribution of AOD and differences in monthly mean of surface maximum temperature $\left(T_{\max }\right)$ and surface minimum temperature $\left(T_{\min }\right)$ during 2000-2015. During February to June-July, mean monthly AOD and difference in monthly $T_{\max }$ and $T_{\min }$ $\left(T_{\max }-T_{\min }\right)$ show significant $(P=0.00108$, i.e., $<0.05)$ high-negative Pearson's correlation (0.9). The comparatively large difference in monthly $T_{\max }$ and $T_{\min }$ during February to June--July results in more unstable atmospheric conditions and therefore there is more movement of AOD in both vertical and horizontal directions and consequently the level of AOD is reduced. From September to January, AOD increases and then begin to decrease until April. The relatively low AOD and relatively maximum difference in $T_{\max }$ and $T_{\min }$ are found in March and April (Pant et al. 2006; Bonasoni et al. 2010; Gobbi et al. 2010; Marinoni et al. 2010; Ram and Sarin 2010). The comparatively minimum difference in $T_{\max }-T_{\min }$ during October, November, December and January (winter month) indicates a relatively stable atmosphere and therefore the level of AOD is increasing during these months. In other words, whenever AOD is more, the more radiation is being trapped into the Earth's atmosphere and therefore the difference between $T_{\max }$ and $T_{\min }$ would be relatively less during winter months.

Almost a similar pattern of AOD over different locations of IGP was found by Lodhi et al. (2013) and Giles et al. (2011). The variation of difference between $T_{\max }$ and $T_{\min }$ over the Gangetic Plain was well supported by Nair et al. (2007).

\section{$3.2 \mathrm{AOD}$ and vorticity at $850 \mathrm{hPa}$ during} the winter season

In recent years, the spatial and temporal variability of AOD over the Gangetic Plain during winter months (December-January-February) (Girolamo et al. 2004; Ramachandran and Cherian 2008) received a lot of importance because of an adverse impact on health, visibility and other atmospheric conditions. Figure $5(\mathrm{a}-\mathrm{c})$ shows a spatial distribution of AOD in December, January and February, respectively. Over foothills of the Himalaya including north Bihar regions, more AOD is seen in December and January months. The spatial changes in AOD may be correlated with wind speed and vorticity over the eastern parts of the Gangetic Plain over Uttar Pradesh, Bihar and West Bengal in India as well as over Bangladesh. Therefore, vorticity at $850 \mathrm{hPa}$ in December, January and February over the study area is shown in figure $6(\mathrm{a}-\mathrm{c})$. The negative vorticity means clockwise rotation of the wind whereas positive vorticity represents anti-clockwise rotation of the wind. The Gangetic Plain is marked by negative vorticity (anti-cyclonic circulation) and positive vorticity (cyclonic circulation) in the east and north sides (foot hills of the Himalaya) which triggers advection of vorticity over the Gangetic Plain. The negative vorticity is found relatively more during January and December with respect to February. The relative strength of negative vorticity over the Gangetic Plain and positive vorticity over the adjacent area may be responsible for more wind dispersion in February compare to December, January and consequently relatively less AOD is noticed in February (as shown in figure 5) with respect to January and December. This could be a cause of shifting of AOD distribution slowly towards West Bengal and Bangladesh regions in February.

\section{Conclusions}

The variability of AOD over the Gangetic Plain (includes here only state of Bihar and Uttar Pradesh) and its relationship with rainfall, surface temperature and vorticity is examined. During JJAS rainfall is correlated with AOD over the Gangetic Plain and both are having inverse correlation. On an average, a difference in mean monthly surface maximum and minimum temperatures increases (decrease) with a decrease 
(increase) in AOD. It seems that strong negative correlation exists between AOD and a difference in $T_{\max }$ and $T_{\min }$ during January to June. In winter months, more AOD is noticed in January, followed by December and February. It seems that dust aerosol is dominated during January-June while anthropogenic aerosol (agricultural waste burning) is dominating in remaining months. The relative strength of negative vorticity over the Gangetic Plain and positive vorticity in the adjacent area may be cause of more dispersion of AOD in February (and shifted to Bangladesh region) in compare to that of December and January and therefore more AOD is seen in January and December.

\section{Acknowledgements}

The authors do not have any conflict of interest and all authors have given consent for publication in the esteemed journal. The authors acknowledge Indian Meteorological Department, India and MODIS for providing us the gridded data.

\section{References}

Ackerman A S, Toon O B, Stevens D E, Heymsfield A J, Ramanathan V and Welton E J 2000 Reduction of tropical cloudiness by soot; Science 288(5468) 1042-1047.

Bell T L, Rosenfeld D, Kim K M, Yoo J M, Lee M I and Hahnenberger M 2008 Midweek increase in US summer rain and storm heights suggests air pollution invigorates rainstorms; J. Geophys. Res.: Atmos. 113(D2).

Bollasina M A, Ming Y and Ramaswamy V 2011 Anthropogenic aerosols and the weakening of the South Asian summer monsoon; Science 334(6055) 502-505.

Bonasoni P, Laj P, Marinoni A, Sprenger M, Angelini F, Arduini J and Biagio C D et al. 2010 Atmospheric brown clouds in the Himalayas: First two years of continuous observations at the Nepal climate observatory-pyramid (5079 m); Atmos. Chem. Phys. 10(15) 7515-7531.

Chung C E and Ramanathan V 2006 Weakening of north Indian SST gradients and the monsoon rainfall in India and the Sahel; J. Clim. 19(10) 2036-2045.

Cowan T and Cai W 2011 The impact of Asian and non-Asian anthropogenic aerosols on 20th century Asian summer monsoon; Geophys. Res. Lett. 38(11).

Dey S, Tripathi S N, Singh R P and Holben B N 2004 Influence of dust storms on the aerosol optical properties over the Indo Gangetic basin; J. Geophys. Res.: Atmos. 109(D20).

El-Askary H, Gautam R, Singh R P and Kafatos M 2006 Dust storms detection over the Indo-Gangetic basin using multi sensor data; Adv. Space Res. 37(4) 728-733.

Freud E and Rosenfeld D 2012 Linear relation between convective cloud drop number concentration and depth for rain initiation; J. Geophys. Res.: Atmos. 117(D2).
Ganguly D, Rasch P J, Wang H and Yoon J H 2012a Climate response of the South Asian monsoon system to anthropogenic aerosols; J. Geophys. Res.: Atmos. 117 (D13).

Ganguly D, Rasch P J, Wang H and Yoon J H 2012b Fast and slow responses of the South Asian monsoon system to anthropogenic aerosols; Geophys. Res. Lett. 39(18).

Gautam R, Hsu N C, Lau K M and Kafatos M 2009a Aerosol and rainfall variability over the Indian monsoon region: Distributions, trends and coupling; Ann. Geophys. 27(9) 3691 .

Gautam R, Hsu N C, Lau K M, Tsay S C and Kafatos M 2009b Enhanced pre monsoon warming over the Himalayan Gangetic region from 1979 to 2007; Geophys. Res. Lett. 36(7).

Giles D M, Holben B N, Tripathi S N, Eck T F, Newcomb W W, Slutsker I K and Singh R P 2011 Aerosol properties over the Indo-Gangetic Plain: A mesoscale perspective from the TIGERZ experiment; J. Geophys. Res.: Atmos. 116(D18).

Girolamo D L, Bond T C, Bramer D, Diner D J, Fettinger F, Kahn R A and Rasch P J et al. 2004 Analysis of multi-angle imaging SpectroRadiometer (MISR) aerosol optical depths over greater India during winter 2001-2004; Geophys. Res. Lett. $\mathbf{3 1}(\mathbf{2 3})$.

Gobbi G P, Angelini F, Bonasoni P, Verza G P, Marinoni A and Barnaba F 2010 Sunphotometry of the 20062007 aerosol optical/radiative properties at the Himalayan Nepal Climate Observatory-Pyramid (5079 m asl); Atmos. Chem. Phys. 10(22) 11,209-11,221.

Goswami B N, Venugopal V, Sengupta D, Madhusoodanan M S and Xavier P K 2006 Increasing trend of extreme rain events over India in a warming environment; Science 314(5804) 1442-1445.

Guo L, Highwood E J, Shaffrey L C and Turner A G 2013 The effect of regional changes in anthropogenic aerosols on rainfall of the East Asian Summer Monsoon; Atmos. Chem. Phys. 13(3) 1521-1534.

Guo J, Deng M, Lee S S, Wang F, Li Z, Zhai P and Li X et al. 2016 Delaying precipitation and lightning by air pollution over the Pearl River Delta. Part I: Observational analyses; J. Geophys. Res.: Atmos. 121(11) 6472-6488.

Guttikunda S K, Carmichael G R, Calori G, Eck C and Woo J H 2003 The contribution of megacities to regional sulfur pollution in Asia; Atmos. Environ. 37(1) 11-22.

Hansen J, Sato M and Ruedy R 1997 Radiative forcing and climate response; J. Geophys Res.: Atmos. 102(D6) 6831-6864.

Huang R J, Zhang Y, Bozzetti C, Ho K F, Cao J J, Han Y and Zotter $\mathrm{P}$ et al. 2014 High secondary aerosol contribution to particulate pollution during haze events in China; Nature 514(7521) 218.

Jiang Y, Liu X, Yang X Q and Wang M 2013 A numerical study of the effect of different aerosol types on East Asian summer clouds and precipitation; Atmos. Environ. 70 $51-63$.

Jimenez J L, Canagaratna M R, Donahue N M, Prevot A S H, Zhang Q, Kroll J H and Aiken A C et al. 2009 Evolution of organic aerosols in the atmosphere; Science 326(5959) 1525-1529.

Jin M, Shepherd J M and King M D 2005 Urban aerosols and their variations with clouds and rainfall: A case study 
for New York and Houston; J. Geophys. Res.: Atmos. 110(D10).

Kaufman Y J and Koren I 2006 Smoke and pollution aerosol effect on cloud cover; Science 313(5787) 655-658.

Kaufman Y J, Tanré D and Boucher O 2002 A satellite view of aerosols in the climate system; Nature 419(6903) 215.

Konwar M, Maheskumar R S, Kulkarni J R, Freud E, Goswami B N and Rosenfeld D 2012 Aerosol control on depth of warm rain in convective clouds; J. Geophys. Res.: Atmos. 117(D13).

Lau K M and Kim K M 2006 Observational relationships between aerosol and Asian monsoon rainfall, and circulation; Geophys. Res. Lett. 33(21).

Lau K M, Kim M K and Kim K M 2006 Asian summer monsoon anomalies induced by aerosol direct forcing: The role of the Tibetan Plateau; Clim. Dyn. 26(7-8) 855-864.

Lau K M, Ramanathan V, Wu G X, Li Z, Tsay S C, Hsu C and Chin $\mathrm{M}$ et al. 2008 The joint aerosol-monsoon experiment: A new challenge for monsoon climate research; Bull. Am. Meteorol. Soc. 89(3) 369-384.

Li Z 2004 Aerosols and climate: A perspective over East Asia; In: Observation, theory and modeling of atmospheric variability: Selected papers of Nanjing Institute of Meteorology Alumni in Commemoration of Professor Jijia Zhang (eds) Xun Zhu, Xiaofan Li, Ming Cai, Shuntai Zhou, Yuejian Zhu, Fei-Fei Jin, Xiaolei Zou and Minghua Zhang, pp. 501-525.

Li Z, Chen H, Cribb M, Dickerson R, Holben B, Li C and Tsay S C et al. 2007 Preface to special section on East Asian Studies of Tropospheric Aerosols: An International Regional Experiment (EAST-AIRE); J. Geophys. Res.: Atmos. 112(D22).

Li Z, Zhao X, Kahn R, Mishchenko M, Remer L, Lee K H and Maring $\mathrm{H}$ et al. 2009 Uncertainties in satellite remote sensing of aerosols and impact on monitoring its long-term trend: A review and perspective; Ann. Geophys. 27(7) 2755-2770.

Li Z, Li C, Chen H, Tsay S C, Holben B, Huang J and Xia X et al. 2011a East Asian Studies of Tropospheric Aerosols and their Impact on Regional Climate (EAST-AIRC): An overview; J. Geophys. Res.: Atmos. 116(D7).

Li Z, Niu F, Fan J, Liu Y, Rosenfeld D and Ding Y 2011b Long-term impacts of aerosols on the vertical development of clouds and precipitation; Nat. Geosci. 4(12) 888.

Lodhi N K, Beegum S N, Singh S and Kumar K 2013 Aerosol climatology at Delhi in the western Indo Gangetic plain: Microphysics, long-term trends, and source strengths; J. Geophys. Res.: Atmos. 118(3) 1361-1375.

Manoj M G, Devara P C S, Joseph S and Sahai A K 2012 Aerosol indirect effect during the aberrant Indian summer monsoon breaks of 2009; Atmos. Environ. 60153 163.

Marinoni A, Cristofanelli P, Laj P, Duchi R, Calzolari F, Decesari S and Bonasoni $\mathrm{P}$ et al. 2010 Aerosol mass and black carbon concentrations, a two year record at NCOP (5079 m, Southern Himalayas); Atmos. Chem. Phys. 10(17) 8551-8562.

Massie S T, Torres O and Smith S J 2004 Total Ozone Mapping Spectrometer (TOMS) observations of increases in Asian aerosol in winter from 1979 to 2000; J. Geophys. Res.: Atmos. 109(D18).
Meehl G A and Arblaster J M 2002 Indian monsoon GCM sensitivity experiments testing tropospheric biennial oscillation transition conditions; J. Clim. 15(9) 923-944.

Meehl G A, Arblaster J M and Collins W D 2008 Effects of black carbon aerosols on the Indian monsoon; J. Clim. 21(12) 2869-2882.

Menon S, Hansen J, Nazarenko L and Luo Y 2002 Climate effects of black carbon aerosols in China and India; Science 297(5590) 2250-2253.

Nair V S, Moorthy K K, Alappattu D P, Kunhikrishnan P K, George S, Nair P R and Niranjan K et al. 2007 Wintertime aerosol characteristics over the IndoGangetic Plain (IGP): Impacts of local boundary layer processes and long-range transport; J. Geophys. Res.: Atmos. 112(D13).

Nair V S, Babu S S, Moorthy K K, Sharma A K, Marinoni A and Ajai 2013 Black carbon aerosols over the Himalayas: Direct and surface albedo forcing; Tellus B, Chem. Phys. Meteorol. 65(1) 19738.

Nakajima T, Yoon S C, Ramanathan V, Shi G Y, Takemura T, Higurashi A and Tsuruta H et al. 2007 Overview of the Atmospheric Brown Cloud East Asian Regional Experiment 2005 and a study of the aerosol direct radiative forcing in east Asia; J. Geophys. Res.: Atmos. 112(D24).

Pandithurai G, Dipu S, Dani K K, Tiwari S, Bisht D S, Devara P C S and Pinker R T 2008 Aerosol radiative forcing during dust events over New Delhi, India; J. Geophys. Res.: Atmos. 113(D13).

Pant P, Hegde P, Dumka U C, Sagar R, Satheesh S K, Moorthy K K and Srivastava M K et al. 2006 Aerosol characteristics at a high-altitude location in central Himalayas: Optical properties and radiative forcing; J. Geophys. Res.: Atmos. 111(D17).

Parth Sarthi P, Ghosh S and Kumar P 2015 Possible future projection of Indian Summer Monsoon Rainfall (ISMR) with the evaluation of model performance in Coupled Model Inter-comparison Project Phase 5 (CMIP5); Glob. Planet. Change 129 92-106, https://doi.org/10.1016/j. gloplacha.2015.03.005.

Parth Sarthi P, Kumar P and Ghosh S 2016 Possible future rainfall over Gangetic Plains (GP), India, in multi-model simulations of CMIP3 and CMIP5; Theor. Appl. Climatol. 124 691-701, https://doi.org/10.1007/ s00704-015-1447-5.

Pisudde P M, Kumar P, Sarthi P P and Deshmukh P R 2017 Climatic determinants of Japanese Encephalitis in Bihar State of India: A time-series Poisson regression analysis; J. Commun. Dis. 49 13-18, https://doi.org/10.24321/ 0019.5138.201729.

Prabha T V, Khain A, Maheshkumar R S, Pandithurai G, Kulkarni J R, Konwar M and Goswami B N 2011 Microphysics of premonsoon and monsoon clouds as seen from in situ measurements during the cloud aerosol interaction and precipitation enhancement experiment (CAIPEEX); J. Atmos. Sci. 68(9) 1882-1901.

Prasad A K, Singh R P and Kafatos M 2006 Influence of coal based thermal power plants on aerosol optical properties in the Indo-Gangetic basin; Geophys. Res. Lett. 33(5).

Prasad A K and Singh R P 2007a Changes in aerosol parameters during major dust storm events (2001-2005) over the Indo-Gangetic Plains using AERONET and MODIS data; J. Geophys. Res.: Atmos. 112(D9). 
Prasad A K and Singh R P 2007b Comparison of MISRMODIS aerosol optical depth over the Indo-Gangetic basin during the winter and summer seasons (2000-2005); Remote Sens. Environ. 107(1-2) 109-119.

Ram K and Sarin M M 2010 Spatio-temporal variability in atmospheric abundances of EC, OC and WSOC over Northern India; J. Aerosol. Sci. 41(1) 88-98.

Ramachandran S and Jayaraman A 2003 Spectral aerosol optical depths over Bay of Bengal and Chennai: I - Measurements; Atmos. Environ. 37(14) 1941-1949.

Ramachandran S and Cherian R 2008 Regional and seasonal variations in aerosol optical characteristics and their frequency distributions over India during 2001-2005; J. Geophys. Res.: Atmos. 113(D8).

Ramachandran S and Kedia S 2010 Black carbon aerosols over an urban region: Radiative forcing and climate impact; J. Geophys. Res.: Atmos. 115(D10).

Ramanathan V and Crutzen P J 2003 New directions: Atmospheric brown 'clouds'; Atmos. Environ. 37(28) 4033-4035.

Ramanathan V, Crutzen P J, Lelieveld J, Mitra A P, Althausen D, Anderson J and Clarke A D et al. 2001 Indian ocean experiment: An integrated analysis of the climate forcing and effects of the great Indo-Asian haze; J. Geophys. Res.: Atmos. 106(D22) 28371-28398.

Ramanathan V, Chung C, Kim D, Bettge T, Buja L, Kiehl $\mathrm{J}$ T and Wild M et al. 2005 Atmospheric brown clouds: Impacts on South Asian climate and hydrological cycle; Proc. Natl. Acad. Sci. USA 102(15) 5326-5333.

Rosenfeld D 2000 Suppression of rain and snow by urban and industrial air pollution; Science 287(5459) 1793-1796.

Roy S S 2008 Impact of aerosol optical depth on seasonal temperatures in India: A spatiotemporal analysis; Int. J. Remote Sens. 29(3) 727-740.

Satheesh S K and Ramanathan V 2000 Large differences in tropical aerosol forcing at the top of the atmosphere and Earth's surface; Nature 405(6782) 60.

Sharma M, Kiran Y N V M and Shandilya K K 2003 Investigations into formation of atmospheric sulfate under high $\mathrm{PM}_{10}$ concentration; Atmos. Environ. 37(14) 20052013.

Singh R P, Dey S, Tripathi S N, Tare V and Holben B 2004 Variability of aerosol parameters over Kanpur, northern India; J. Geophys. Res.: Atmos. 109(D23).

Singh S, Nath S, Kohli R and Singh R 2005 Aerosols over Delhi during pre-monsoon months: Characteristicsand effects on surface radiation forcing; Geophys. Res. Lett. $32(13)$.

Solmon F, Nair V S and Mallet M 2015 Increasing Arabian dust activity and the Indian summer monsoon; Atmos. Chem. Phys. 15(14) 8051.

Song F, Zhou T and Qian Y 2014 Responses of East Asian summer monsoon to natural and anthropogenic forcings in the 17 latest CMIP5 models; Geophys. Res. Lett. 41(2) 596-603.

Streets D G, Yan F, Chin M, Diehl T, Mahowald N, Schultz $\mathrm{M}$ and $\mathrm{Yu} \mathrm{C}$ et al. 2009 Anthropogenic and natural contributions to regional trends in aerosol optical depth, 1980-2006; J. Geophys. Res.: Atmos. 114(D10).

Tripathi S N, Tare V, Chinnam N, Srivastava A K, Dey S, Agarwal A and Chauhan S S S et al. 2006 Measurements of atmospheric parameters during Indian Space Research Organization Geosphere Biosphere Programme Land Campaign II at a typical location in the Ganga basin: 1. Physical and optical properties; J. Geophys. Res.: Atmos. 111(D23).

Wang B, Huang F, Wu Z, Yang J, Fu X and Kikuchi K 2009a Multi-scale climate variability of the South China Sea monsoon: A review; Dyn. Atmos. Oceans 47(1-3) $15-37$.

Wang C, Kim D, Ekman A M, Barth M C and Rasch P J 2009b Impact of anthropogenic aerosols on Indian summer monsoon; Geophys. Res. Lett. 36(21).

Zhang H, Wang Z, Guo P and Wang Z 2009 A modeling study of the effects of direct radiative forcing due to carbonaceous aerosol on the climate in East Asia; Adv. Atmos. Sci. 26(1) 57-66.

Zhang L, Liao H and Li J 2010a Impact of the Southeast Asian summer monsoon strength on the outflow of aerosols from South Asia; Ann. Geophys. 28(1) 277.

Zhang L, Liao H and Li J 2010b Impacts of Asian summer monsoon on seasonal and interannual variations of aerosols over eastern China; J. Geophys. Res.: Atmos. 115(D7).

Zhang H, Wang Z, Wang Z, Liu Q, Gong S, Zhang X and Li L et al. 2012 Simulation of direct radiative forcing of aerosols and their effects on East Asian climate using an interactive AGCM-aerosol coupled system; Clim. Dyn. 38(7-8) $1675-1693$.

Zhou L, Dickinson R E, Tian Y, Fang J, Li Q, Kaufmann R $\mathrm{K}$ and Myneni R B et al. 2004 Evidence for a significant urbanization effect on climate in China; Proc. Natl. Acad. Sci. USA 101(26) 9540-9544. 